\title{
A Study on Urban Modal Split and its Development in Salem City
}

\author{
R. Naveen and A. Sivakumar
}

\begin{abstract}
An analysis of modal split is essential in transportation studies. The concept of modal split is simple, but there is considerable confusion in the literature between the terms "mode choice" and "modal split". The term mode choice refers to the process, where the traveler chooses a particular mode for his trip.His choice is made simultaneously with the decision to travel, the choice of destination and the route to be taken. The term, modal split is taken as the proportionate division of the total number of person trips between various means or modes of travel. It is the process of separating persons -trips by the mode of travel such as buses, trains, etc. The main objective of the project is to analyses the modal split in the Salem city by collecting suitable data among the passengers such as origin, destination, income level, trip purpose, trip frequency, reason for their mode choice etc. By using this data the existing characteristics are studied and we can predict the modal split analysis for the future development in Passenger transport. This criteria has been analyzed using passenger opinion survey and necessary related surveys were done to study the present scenario which is familiar to collect the information among the passengers.
\end{abstract}

Keywords--- Mode Choice, Modal Split, Origin, Destination, Trip Frequency.

\section{INTRODUCTION}

$S^{A}$ ALEM is the one of the town of Tamil Nadu located in the Western part of the southern most state of India. Almost completely surrounded by hills, Salem is one of the major textile centers in the World.

Salem city had population of about 693,236 according to the census of 2001. Also a survey of 2006 says that the current estimated population is about 8.4 lakhs. Also Salem city is said to be the fifth largest city in Tamil Nadu in landscape.

Salem city is also called as Steel City, agro city, limestone city, electric city, and mango city.

The city has been growing over the past three decades due to the increasing birth rate and more migration towards the city from rural area for the purpose of employment, business and education etc.

The increase in crowd of core cities bound to create severe problems available in the infrastructure. There are five

R. Naveen, Post Graduate Student, Department of Civil Engineering, Kongu Engineering College, Perundurai, Erode.

A. Sivakumar, Assistant Professor, Department of Civil Engineering, Kongu Engineering College, Perundurai, Erode.

DOI: 10.9756/IJRAS.8148 characteristics of the trip making behavior that draws special attention: Trip purpose, Trip frequency, Reason for this mode choice, Education level, Job details \& income level. Urban modal split is a process that makes decisions on urban transportation policies and programmers. In this study, the analysis is confined to only one stage of travel demand modeling, i.e. Modal Split.

The main objective of the project is to analyses the modal split in the Salem city by collecting suitable data among the passengers such as origin, destination, income level, trip purpose, trip frequency, reason for their mode choice etc. To study the trends in existing modal split and its influence on the level of service over a period of time in Salem city. By using this data the existing characteristics are studied and we can predict the modal split analysis for the future development in Passenger transport.

This criteria has been analyzed using passenger opinion survey and necessary related surveys were done to study the present scenario which is familiar to collect the information among the passengers. Based on the study, suggestions will be given for future development in the city.

\section{Methodology}

In this project, by collecting suitable data among the passengers such as origin, destination, income level, trip purpose, trip frequency, reason for their mode choice etc. we can study the trends in existing modal split and its influence on the level of service over a period of time in Salem city. Collection of data among passenger is known as passenger opinion survey.

It is the type of survey which is collected from the passengers in bus stand and railway station. This survey is very useful to predict the future scenario of the future development in transportation planning.

The major data to be collected from the passengers are origin of the trip, destination of the trip, trip distance, trip cost, trip purpose, trip frequency, education level, job detail and monthly income.

This survey is carried over for several days, until the needed sample is taken from the passengers. In Salem city, we collected ' $\mathrm{N}$ ' numbers of samples in various days among different age groups.

We carried our opinion survey obviously around $6 \mathrm{pm}$ and ended at 10pm. The personality of this project is to collect the data without causing any disturbance to the public. The main scenario of this data collection is to study the present strength of transport modes and suggest our opinion about modal split 
analysis in future transportation planning.

The analysis of the data is done separately for the two sectors: Bus Terminal and Railway Station.

\section{CHOICES FOR DATA SHEET}

\section{A. Trip Frequency}
1. Daily.
2. Weekly.
3. Monthly.
4. Occasionally.

B. Reason for this Mode Choice
1. Cheap.
2. Fast.
3. Comfortable.
4. Others (Mention).

C. Purpose of Journey
1. Work.
2. Business.
3. Education.
4. Social \& Recreation.
5. Tourism.
6. Others.

\section{Education Level}
1. School.
2. Diploma.
3. Degree.
4. PG degree.
5. Illiterate.

\section{E. Job Details}
1. Government.
2. Private.
3. Public sector.
4. Business / Self.
5. Retired.
6. Agriculture.
7. Others (Mention).

F. Monthly Income
1. $<10,000$.
2. $10,001-25,000$.
3. $25,001-50,000$.
4. $>50,000$.

\section{Results And Discussion}

In this project, 500 passengers had reviewed and their opinions have been collected successfully in the bus terminal. By using this collected data, the percentile scenario had calculated for each and every category and the comparison have been done and it was shown clearly on the below table. These values are plotted clearly on the pie chart for clear identification of category wise.
Passengers Travelled In Each Category in Percentage

\begin{tabular}{|c|c|c|}
\hline BASED ON & CHOICES & $\begin{array}{c}\text { BUSTAND } \\
(\%)\end{array}$ \\
\hline \multirow{4}{*}{$\begin{array}{l}\text { TRIP } \\
\text { FREQUENCY }\end{array}$} & DAIIY & 2.6 \\
\hline & WEEKLY & 16.8 \\
\hline & MONTHLY & 27.2 \\
\hline & OCCASSIONALLY & 53.4 \\
\hline \multirow{4}{*}{$\begin{array}{l}\text { REASON FOR } \\
\text { THIS MODE } \\
\text { CHOICE }\end{array}$} & CHEAP & 20.6 \\
\hline & FAST & 9.4 \\
\hline & COMFORTABLE & 58.2 \\
\hline & OTHERS & 11.8 \\
\hline \multirow{6}{*}{$\begin{array}{l}\text { PURPOSE OF } \\
\text { JOURNEY }\end{array}$} & WORK & 29.4 \\
\hline & BUSINESS & 13.6 \\
\hline & EDUCATION & 16.6 \\
\hline & $\begin{array}{l}4 . \quad \text { SOCIAL \& } \\
\text { RECREATION }\end{array}$ & 3.4 \\
\hline & 5. $\quad$ TOURISM & 8 \\
\hline & OTHERS & 29 \\
\hline \multirow{5}{*}{$\begin{array}{l}\text { EDUCATION } \\
\text { LEVEL }\end{array}$} & SCHOOL & 32 \\
\hline & DIPLOMA & 8 \\
\hline & DEGREE & 34.6 \\
\hline & PG DEGREE & 13.2 \\
\hline & ILLITERATE & 12.2 \\
\hline \multirow{7}{*}{ JOB DETAIIS } & GOVERNMENT & 9.8 \\
\hline & PRIVATE & 40.2 \\
\hline & PUBLIC SECTOR & 1.4 \\
\hline & BUSINESS/SELF & 8.8 \\
\hline & RETIRED & 0.6 \\
\hline & AGRICULTURE & 7.4 \\
\hline & OTHERS(MENTION) & 1.8 \\
\hline
\end{tabular}

Based On Trip Frequency

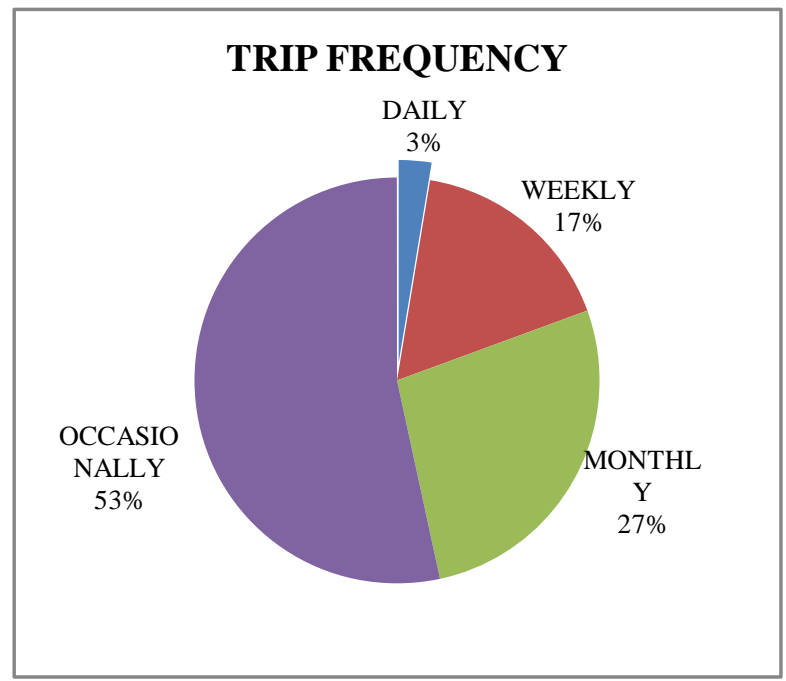

Based on daily Trip Frequency, our survey suggests 3 percent of passengers are moved through buses. Based on weekly Trip Frequency, our survey suggests 17 percent of passengers are travelled through buses. Based on monthly Trip Frequency, our survey suggests 27 percent of passengers are moved through buses. Based on occasionally Trip Frequency, our survey suggests 53 percent of passengers are travelled through buses. Hence, this survey stats more than half of the percentage of passengers are travelling occasionally(Trip Frequency) from salem to chennai through buses. 


\section{Based on Mode Choice}

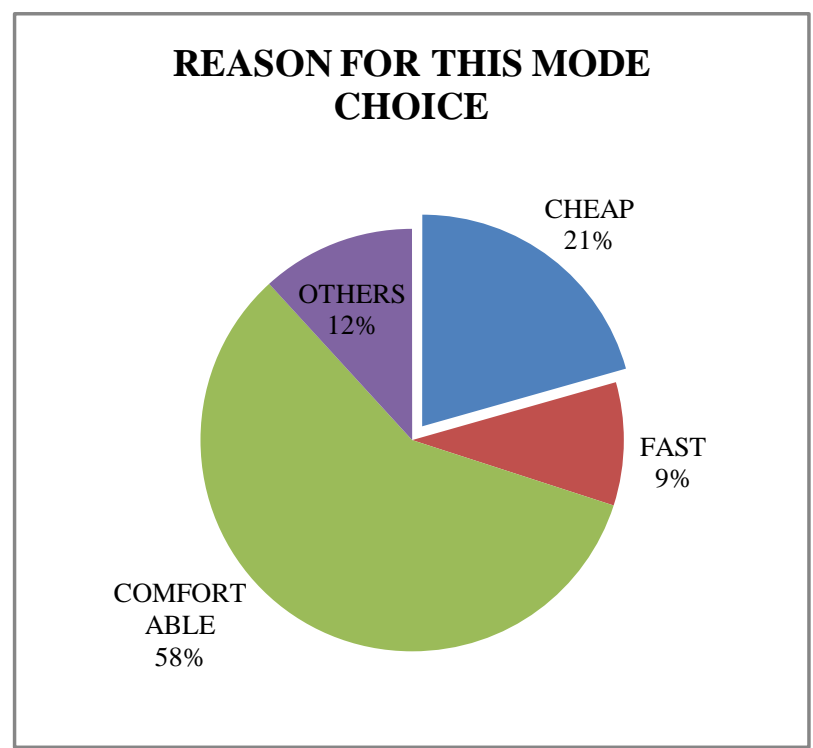

Based on mode choice (cheap), our survey suggests 21 percent of passengers feels buses are cheap. Based on mode choice (fast), our survey suggests 9 percent of passengers feels buses are fast. Based on mode choice (comfortable), our survey suggests 58 percent of passengers feels buses are comfortable. Based on mode choice (others), our survey suggests 12 percent of passengers prefer buses for other reasons. Hence, this survey stats majority of the percentage of passengers feels buses are comfortable for travelling from Salem to Chennai.

\section{Based on Purpose of Journey}

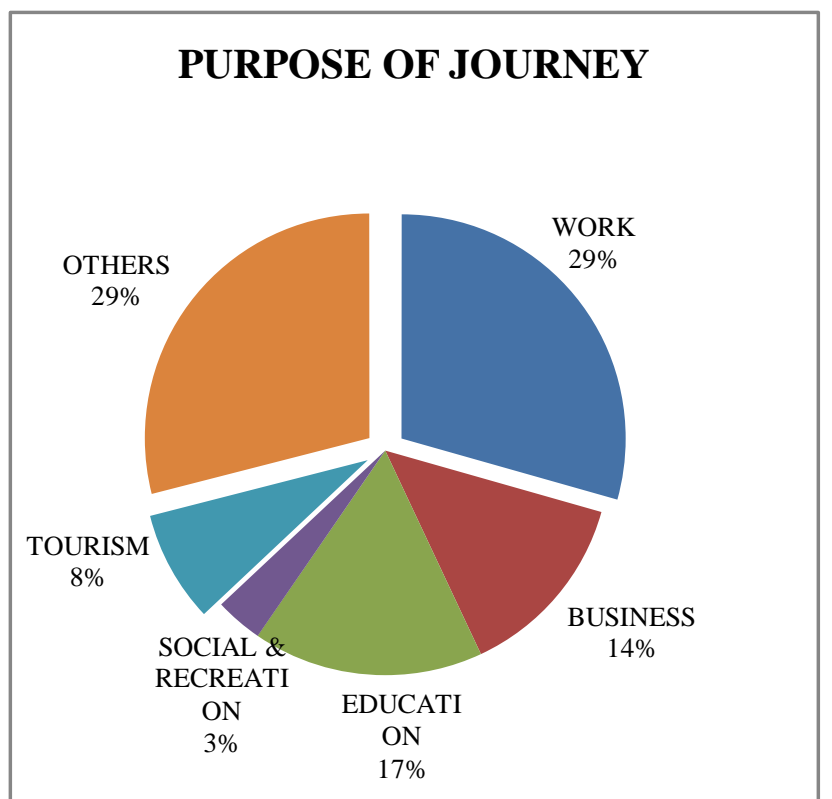

We all know India is a developing country and hence day by day there is a increase in economy, so the people who travelled in buses are mostly moving for the purpose of work and business. Our survey suggests, 43 percent of passengers travelled for work and business purposes in buses. And 17 percent passengers are travelled for education purpose and 3 percent for social purpose and 8 percent for tourism. 29 percentage of passengers are travelled in buses for other reason like hospital, sports, personal reasons, etc,.

\section{Based on Education Level}

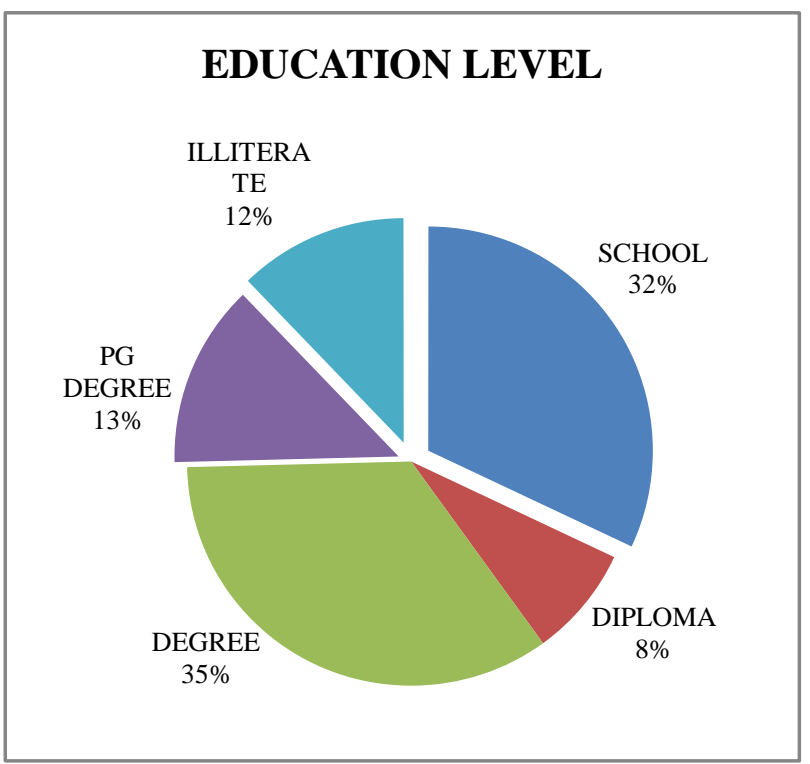

Based on the education level of the passengers who have been travelled from Salem to Chennai, 32 percent passengers have been educated up to school level. 8 percent passengers have been educated up to diploma level. 35 percent passengers have been pursuing or completed a degree. 13 percent passengers have been pursuing or completed a PG degree. Only 12 percent of the passengers have been illiterate. In future, the percentage of illiterate will be surely decreased because nowadays education is become compulsory in developing society.

\section{Based on job Details}

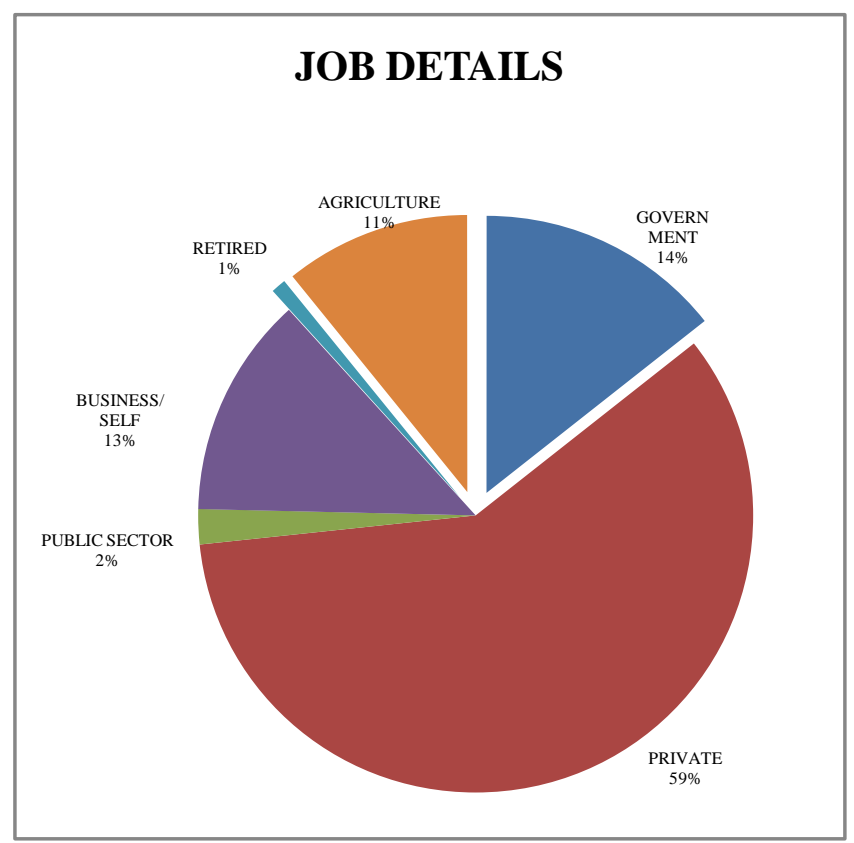

In free economic countries, the private sector is wider and places less constraints on firms. In countries with more government authority, public sector makes up most of the economy. Here our survey suggests, 14 percent are 
government employees, 59 percent are private employee and 2 percent are public sector employees.13 percent of the passengers are business or self employees. And 1 percent are retired employees. And 11 percent are doing agriculture (Farmers). From this graph, we can clearly pictured the role of private sector in our country.

\section{CONCLUSION}

From this study the following observations has been made, People around the study area mostly use public transit for performing work and education activities. For shopping and other recreational activities people prefer private mode of travel. So data is collected only in an area of public mode of transport. Nearly $50 \%$ of passengers are moving from Salem to Chennai for the work and business purposes and $25 \%$ for education purposes. This data collection is done on various age groups. After a period of 10 years Population is expected to become one and half times of current population but immigration rate will gradually deteriorate. Our study states, Buses are mostly preferred in Salem city at present for the purpose like work, business, education, etc, $\ldots$ because buses are safety, connectivity's are good, often occurred in many numbers, etc,... By this study I can able to predict, movement of people through public transport is moving mostly by Buses. Hence I conclude my study by saying, in future movement of people will increase and may vary due to the development in all sectors now a days.

Still I need to carry my passenger opinion survey in Railway station and I have to analyze the percentage criterion in each category and then these results are to be matched with data collected in Bus stand and then I can able to predict whether movement of people through public transport is moving mostly by Buses or Trains.

\section{REFERENCES}

[1] P. Waddell, "UrbanSim: Modeling urban development for land use, transportation, and environmental planning”, Journal of the American planning association, Vol. 68, No. 3, Pp. 297-314, 2002.

[2] D. He, F. Meng, M.Q. Wang and K. He, "Impacts of urban transportation mode split on CO2 emissions in Jinan, China”, Energies, Vol. 4, No. 4, Pp. 685-699, 2011.

[3] J.D. De Abreu and F. Santos, "Urban Density and modal split: analysis of two Portuguese medium cities”, In Proceedings of ETC, Transport Policy And Operations-Planning For Sustainable Land Use and Transport-Land Use and Transport Interactions II, Vol. 4, Pp. 193-199, 2005.

[4] L.R. Kadiyali, "Traffic engineering and rrasport planning”, $4^{\text {th }}$ edition, Pp. 89-95, 2005.

[5] B. Kent Lall and C. Jotin Khisty, "Transportation engineering and manangement”, $5^{\text {th }}$ edition, Pp. 147-151, 2008.

[6] K.V. Krishna Rao, "Behavioral travel modeling", Vol. 1, Pp. 200-210, 2005.

[7] S. Manju, "Modal split models for madras", Vol. 1, Pp. 98-110.

[8] D. Mohan, "Public transportation 1989systems for urban areas", Vol. 2, Pp. 65-67, 2006.

[9] MoUD and Gol, "Study on traffic and transportation policies and strategies in urban areas in India”, $3^{\text {rd }}$ edition, Pp. 56-60, 2008.

[10] H. Noboru and K. OHfn, "The combine modal split/Assignment model in the Tokyo metropolitan area”, Vol. 2, Pp. 165-170, 1995. 